Portland State University

PDXScholar

Summer 8-9-2013

\title{
Why Occupy?: Principal Reasons for Participant Involvement in Occupy Portland
}

Danielle Filecia

Portland State University

Follow this and additional works at: https://pdxscholar.library.pdx.edu/open_access_etds

Part of the Civic and Community Engagement Commons, and the Politics and Social Change Commons

Let us know how access to this document benefits you.

\section{Recommended Citation}

Filecia, Danielle, "Why Occupy?: Principal Reasons for Participant Involvement in Occupy Portland" (2013). Dissertations and Theses. Paper 1098.

https://doi.org/10.15760/etd.1098

This Thesis is brought to you for free and open access. It has been accepted for inclusion in Dissertations and Theses by an authorized administrator of PDXScholar. Please contact us if we can make this document more accessible: pdxscholar@pdx.edu. 
Why Occupy?: Principal Reasons for Participant Involvement in Occupy Portland

$$
\text { by }
$$

Danielle Filecia

A thesis submitted in partial fulfillment of the requirements for the degree of

\author{
Master of Science \\ in \\ Conflict Resolution
}

\title{
Thesis Committee: \\ Robert Gould, Chair \\ Rachel Cunliffe \\ Robert Liebman
}

\section{Portland State University}

2013 
(C) 2013 Danielle Filecia 


\begin{abstract}
$\underline{\text { Abstract }}$
Occupy Wall Street galvanized the country and attracted thousands of participants, who came to New York City in order to protest corporate greed. Occupy Portland, standing in solidarity with Occupy Wall Street, began their encampment less than a month later and attracted more participants on its first day than did Occupy Wall Street. This grounded theory inquiry uncovers the principle reasons why individuals participated in Occupy Portland. The findings revealed that participants were (1) upset about the bank bailouts and corporate irresponsibility; (2) swept up by the size and organization of Occupy; and (3) looking to get some fundamental societal needs met. The findings do not neatly fit collective behavior or resource mobilization theory, paving the way for further scholarship.
\end{abstract}




\section{Dedication}

I would like to dedicate this to my mother and to all single moms who are part of the $99 \%$ and who are trying to provide a good life for their children in a world of corporate greed and exploitation. 


\section{Acknowledgments}

First and foremost I would like to thank Rachel Cunliffe who, over the past one and a half years has counseled and advised me through each stage of the thesis writing process. I am forever grateful for her time, patience, and caring guidance.

I would also like to thank the rest of my thesis committee; Robert Gould and Robert Liebman, for their time, flexibility, advice, and for their understanding in helping me push this through in such a short timeline.

Finally, I want to thank my friends here in Portland, and elsewhere, for their everlasting love, support, and editing skills. Without you, I would have not made it through this process. 


\section{Table of Contents}

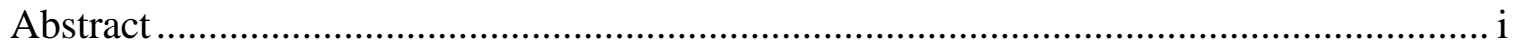

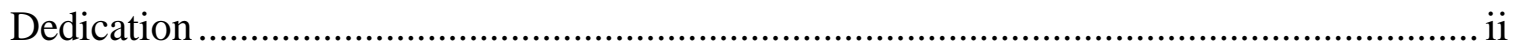

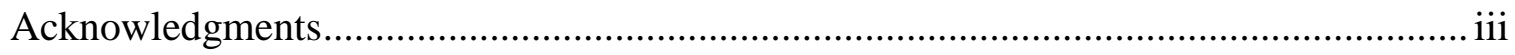

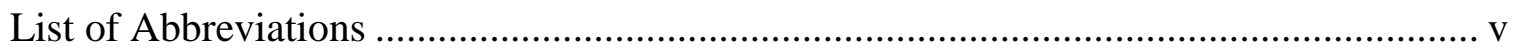

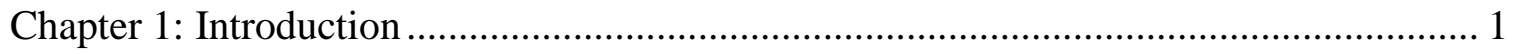

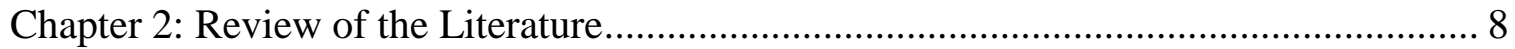

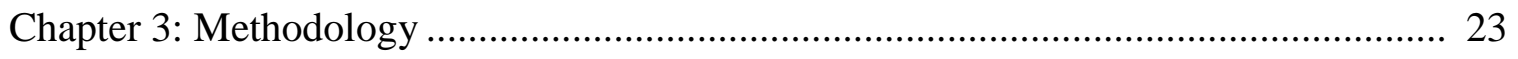

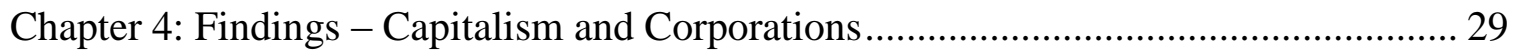

Chapter 5: Findings - Large Scale Mobilized Revolution .......................................... 38

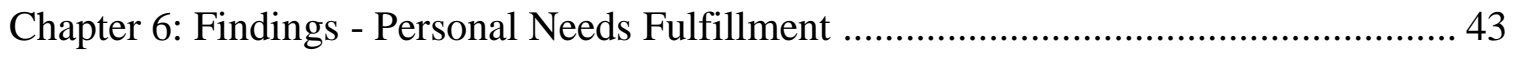

Chapter 7: Conclusions, Implications and Recommendations .................................... 51

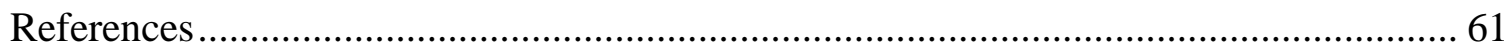

Appendix A: Human Subjects Research Proposal ................................................... 65

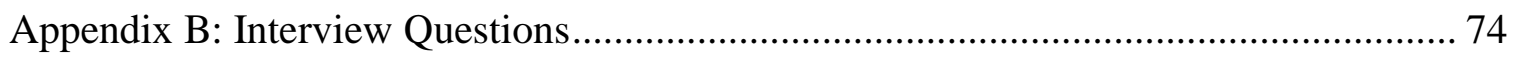

Appendix C: Participant Demographic Information .............................................. 75 


\section{$\underline{\text { List of Abbreviations }}$}

Adbusters Magazine

Conflict Resolution

Congressional Budget Office

General Assembly

International Monetary Fund

New York Police Department

North America Free Trade Agreement

November 17, 2011

Occupy Portland

Occupy Wall Street

Resource Mobilization

Social Movement Organization

World Trade Organization
Adbusters

CR

CBO

GA

IMF

NYPD

NAFTA

N17

OPDX

OWS

$\mathrm{RM}$

SMO

WTO 


\section{Chapter 1: Introduction}

On September $17^{\text {th }} 2011$, individuals from across the United States converged on Wall Street to form "a leaderless resistance movement with people of many colors, genders and political persuasions" (Occupy Wall Street, 2011). Those who identify with these protest activities claim to be part of the $99 \%$, and are unified by the fact that they "will no longer tolerate the greed and corruption of the 1\%" (Occupy Wall Street, 2011). According to the Congressional Budget Office (CBO), between 1979 and 2007, the top one-fifth of the population saw a $10 \%$ increase in their share of after-tax income. Most of that growth, however, went to the top $1 \%$, whose income increased by $275 \%$. Meanwhile, all other groups saw their shares of total income decline by 2 to 3 percentage points (Hellman, 2011). Therefore, Occupy Wall Street exists in an environment where many Americans are feeling the effects of the 2008 economic collapse. For example, between 2008 and 2009, the average American household saw a reduction in income of $\$ 5,500$. Additionally, the United States lost $\$ 3.4$ trillion in real estate value between July 2008 and March 2009; that is about \$30,300 per household. The economic collapse, coupled with the disparity in growth between top earners and the middle class, led to Occupy Wall Street, which quickly became a worldwide phenomenon.

In the following section, I will provide context for, and an overview of, the rest of the paper. First, I explain why I am writing about this topic and how I came to my research question. Next, I provide further explanation and context for Occupy Wall Street and its relationship to Occupy Portland and similar, unrelated, actions, across the world. 


\section{Researchers Stance to the Study}

The topic of this thesis came to me from the experience of my family during the recent economic crisis--specifically, the mortgage crisis. When we lost our savings, our home, and most of our worldly possessions, there was a collective feeling of shame, anger, and guilt, which I sat with for 3 years. When it came along, the Occupy movement seemed to legitimize and, to some degree, eradicate these feelings. Growing up, I held the belief that if a person works hard they will be able to provide for their family, and have a good life. Further, if that person is especially talented, creative, and innovative, they can start a small business, and have more money or security than everyone else. In brief, I thought that the risk one takes is worth the payoff. I always assumed capitalism was a system that rewards ingenuity and hard work.

These beliefs have been consistent with my experiences growing up in the United States. I was raised by a single mother and we have never had much money. Things were so bad that, when I was eleven, we were living in a house without water or electricity. Soon my mother was unable to provide shelter for us, so she sent me to live with my father. During that time, my mom continued to work hard, was creative, took risks, and started her own business. Three years later, when I was fourteen, we were moving into a five bedroom house in Hollywood Hills, and I was enrolled in private school. For the next ten years, things continued to go well financially for my mom, as she worked day and night to maintain our lifestyle.

In 2008, we saw the beginning of what would become a very difficult time in our life, during which, we would lose most of our possessions. My mom's business was 
quickly declining and so was our financial stability. Soon thereafter, she was selling household items, and the vultures started to circle. At this time, my mom was working tirelessly in a vain attempt to provide basic necessities for my younger brothers, who are 16 and 19 years younger than I am, that is they were around 9 and 12 years old at this time. Eventually, our house was stripped bare; everything was sold, including the furniture, refrigerator, and oven. Her car was repossessed (a real problem when you live in the hills), and the Sheriffs kicked her and my brothers out of our house. This landed my mother homeless and alone, much like before, except this time, she was much older and had two kids and no resources, friends, or family to help. Watching this happen, and being completely powerless over these circumstances, broke my heart. There were long periods of time I could not talk to her, because it was too difficult for me to hear her crying, and to witness her anguish. Watching my mom lose everything was very sad, but the fact that she could not help herself, or my younger brothers, despite her eagerness and willingness to work, was frustrating and demoralizing.

When the bank came and took the house I spent much of my adolescence in, I did not tell anyone. When my mom's car was repossessed and she became stranded, when she had to sell everything in the house, I did not tell anyone. The feeling of being poor, ashamed, and judged made me feel like I was that eleven-year-old kid again. Also, I blamed her; I was angry at her for allowing this to happen again, for not coming up with better ideas, for not working harder, for putting all of us in this uncomfortable and shameful situation. I did not want anyone to know what had happened, that my mother had failed us by allowing the bank to take our house. I felt immense guilt and shame for 
allowing this to happen to my family, which I could have supported having earned a law degree and, at the time, having more than one job offer to work in the legal field. During this time my mom called me up crying at least once a week, it broke my heart. I was sad, confused, and very angry.

Something always seemed unclear to me about my mother's financial decline, and how we lost our house. At some point, during our financial decline, my mother asked me to put our house in my name so that she could take a loan out on it because of my good credit. I agreed and was fully aware of the risk. At the time I did not think much of it, but when the bank came and took the house I started to wonder why they would loan so much money to a twenty-four-year-old with no job and sixty thousand dollars of student loan debt. Also, I could not help but wonder what kind of world I was living in that a single mother with two kids was pushed out of her home and left with nothing.

Meanwhile, the United States was embroiled in two wars abroad that we were sinking trillions of dollars into every year. It was later revealed that banks were engaged in predatory lending practices targeting people for loans and that the executives of these major banks were getting record bonuses. For me, watching this banking crisis unfold was almost like watching a fictional movie. Banks used predatory lending to target people without evaluating whether or not they would be able to pay back their loans. Many people were unable to pay their mortgages which led to a financial collapse and foreclosures. While all of this was happening the people in these banks were getting bonuses, and eventually, the banks were bailed out using billions of American tax dollars. 
Moreover, I watched the larger banks buy out so many of the local community banks in Los Angeles where I grew up.

So here I was, watching my mother struggle for a place to live, while banks continued to kick people out of their homes, keep the money people had paid toward their mortgage, write it off as a loss, keep the property to resell, and get bailed out. The amount of rage that I felt from watching this happen is indescribable. I was feeling angry, betrayed, and powerless. I was also still experiencing shame and isolation because of our losses. Mostly I was feeling alone. I had a lot of rage toward these banks and large corporations; I did not know what to do with that anger, where to put it, or how to direct it in a useful way. I sort of just allowed it to exist, and tried to not let it get the best of me.

A year later I moved out of Los Angeles and two years after that came Occupy Wall Street. Here was a group of people talking about the things I was ashamed of, I had kept secret, I feared judgment for, and over which I had isolated myself. Not only were they talking about these things, but they were standing up and saying that what is happening with the banks and greed of corporations is wrong, and that it is not the fault of the people who are affected by this behavior. Here was a group of Americans saying that the fault was not ours - not my mom's, not mine-but the banks' and the government.

My feelings of loneliness and isolation dissipated immediately. It was almost as if the cloak of shame that I had been wearing all of those years was removed. The sense of empowerment and strength that I felt from attending Occupy actions was, and still is, 
one of the most profoundly life altering experiences I have had. Not only did I feel redeemed - released from the pain and suffering of my experiences — but it provided me with a place to channel my anger and sadness over what had happened to my family. I finally began to heal.

I started to have honest, and direct, conversations with people about my experiences; this was something new for me. Suddenly, the person behind the counter at Sears was telling me how her brother lost his house. Friends were relaying stories about their parents' lost retirement. Just about everybody I ran into knew somebody who lost a house or a job due to the economic downturn. I viewed Occupy Wall Street as a place where these people were represented, where they had voice, and where they were part of something bigger than themselves, even bigger than the banks.

Since the inception of Occupy Wall Street, and my participation in Occupy Portland, those feelings of shame, and loneliness, have not come back. This movement has given me space for personal transformation and an opportunity to transcend my shame. I believe Occupy is unique in its purpose, timing, and structure and I think it is an area that is ripe for academic exploration. Mostly though, I am curious about the principal reasons that others participate(d) in Occupy Portland.

\section{Overview of the Study}

In addition to an analysis of the literature based in social movement theory and conflict resolution, I will review the scant academic material that is available about Occupy. Because Occupy is a fairly recent phenomenon, academia has not yet had the chance to produce much in the way of peer-reviewed, and expert explanation and 
analysis. The books that are written are predominantly firsthand accounts, and include speeches, and short pieces written by journalists and some academics. There are a handful of peer-reviewed articles with few references as to why people participate. Additionally, the literature focuses mostly on Occupy Wall Street (OWS), and occasionally references Occupy actions in other large cities. Occupy Portland states its intention to stand in solidarity with OWS, therefore many of the general themes, topics, and issues from OWS are applicable here. Where they exist, differences are noted. Much of the information about OPDX comes from newspapers, blogs, and editorials.

In my discussion of Occupy I will review local and international events that have helped create an environment ripe for change. Such events as the Spanish Indignado movement, the occupation of the state capitol in Wisconsin, the popularity of Wikileaks, and the Arab Spring, will be addressed. I believe that, for one to understand such a significant historical moment as Occupy, one must also understand the atmosphere and recent history that gave rise to the moment. Occupy is a context driven event, and in my discussion, I hope to draw a clear picture of the circumstances leading to its creation and popularity. 


\section{Chapter 2: Review of the Literature}

This chapter presents a review of the literature on social movement theory and on Occupy Wall Street and Occupy Portland. In my discussion of the literature I will include scholarship from both Sociology and Conflict Resolution. The two areas differ in their approaches and study of protest activity. The sociology literature, focusing on social movements, is mostly theory based and considers its audience to be individuals located in academia, whereas Conflict Resolution is more experiential and seeks to combine theory and practice, and seeks to appeal to those who participate in protests and social movement activities as its audience (Roy, Burdick, \& Kriesberg, 2010).

In the discussion of social movements, explanation of collective behavior and resource mobilization are provided. The examination of Conflict Resolution literature emphasizes nonviolent political action, and civil disobedience. The analysis of Occupy provides an overview of Occupy Wall Street and discusses the economic and political factors that led to its inception. In the discussion of Occupy Portland, I begin with an overview and go on to look at the encampment, public participation, and its current state.

\section{Social Movement Theory}

There is a lot of controversy and a variety of opinions over what characterizes a social movement. Social movements can be thought of as the "[c]ollective and sustained efforts that challenge existing or potential laws, policies, norms, or authorities, making use of extrainstitutional as well as institutional political tactics.” (Meyer, 2007, p. 9) Others view social movements as activities which lead to the transformation, or creation, of new social identities for the actors (Eyerman \& Jamison, 1991). Sydney Tarrow, a 
preeminent scholar in the study of social movements, defines social movements as "those sequences of contentious politics that are based in underlying social networks and resonant collective action frames, and which develop the capacity to maintain sustained challenges against powerful opponents" (Tarrow, 1998, p. 2). According to prevailing definitions in the field, contentious politics can be described as "episodic, public, collective interaction among makers of claims and their objects when (a) at least one government is a claimant, an object of claims, or a party to the claims, and (b) the claims would, if realized, affect the interests of at least one of the claimants" (McAdam, Tarrow, \& Tilly, 2001).

The study of social movements and political protest originated in the 1930's and 40's in an attempt to explain the rise of Hitler in Germany. At this time scholars were looking at crowd formation and collective behavior, in order to understand fascism. Because of the events leading to these studies social movements were viewed with disdain, scholars wanted to understand why the tragedies and atrocities from that event happened and focused their attention on the unchecked behavior of large groups. At the time, social movements were thought of as alternatives to traditional politics and civilized political engagement. Because of such origins scholars were concerned with why social movements came about in seemingly healthy democracies (Meyer, 2007).

Collective behavior. Up until the end of the 1960's, the prevailing theory for social movements emphasized individual participation. Collective behavior places emphasis on individual grievances and values resulting from rapid social change (Cohen, 1985). This view looks at social movements as spontaneous events involving like 
minded individuals. Through these spontaneous gatherings a collective identity emerges that cannot simply be explained through the agency of individual actors but is the byproduct of such individuals coming to together in a group. What scholars at this time theorized about collective action is that large groups are capable of disrupting societal norms and mobilizing in order to bring about social change. (McCarthy \& Zald, 1977). This theory emphasizes the significance of spontaneity in various forms of political engagement and views social movements as nothing more than organized manifestations of such spontaneity (Freeman, 1999).

In these early years of social movement scholarship, participation in such movements was viewed as either highly adaptive or merely deviant behavior and was explained by attributing involvement to either shifts in individual attitudes and beliefs or responses to structural strain. Such varying opinions about reasons for participation began to surface toward the end of the 1960s and resulted in many competing schools of thought within the study of collective behavior (Eyerman \& Jamison, 1991).

However, despite the divergent conceptions of collective behavior in the field there are some common assumptions underlying all variations of the theory, these are summarized succinctly by Jean Cohen (1985) as follows:

there are two distinct kinds of action: (1) institutional-conventional and noninstitutional-collective behavior. (2) Non-institutionalcollective behavior is action that is not guided by existing social norms but is formed to meet undefined or unstructured situations. (3) These situations are understood in terms of a breakdown either in the organs of social control or in the adequacy of normative integration, due to structural changes. (4) The resulting strains, discontent, frustration, and aggression lead the individual to participate in collective behavior. (5) Noninstitutional-collective behavior follows a "life cycle," open to causal analysis, which moves from spontaneous crowd action to the 
formation of publics and social movements. (6) The emergence and growth of movements within this cycle occurs through crude processes of communication: contagion, rumor, circular reaction, diffusion, etc. (p. 671)

Considering the foregoing, what seems to be the general feeling and criticism about this approach is that it views social movements as disorganized mechanisms reacting to societal discontent. The collective behavior analysis of social movements does not acknowledge, or account for, those incidents that may be well organized, or highly coordinated, and require intentional agency of individuals, which is where much of the criticism comes from, and eventually an abandonment of this theory in favor of one that embraces such factors.

Resource Mobilization. The widespread student protests of the 1960's came as a surprise to many sociologists. Such actions were primarily issue driven, addressing such social and political topics as civil rights, feminism, and war. Collective behavior provided no explanation or justification for why privileged middle class University students would join these movements. Such actions puzzled scholars, operating under the prevailing theory, because the students were neither deviant characters pushed to the fringes of society, nor were they societal outcasts being crushed by structural strain, which is who was believed to take part in such activities (Eyerman \& Jamison, 1991).

Additionally, since many of the social movements during the 1960's involved university students and others in higher education, those who participated in movements personally began to make scholarly contributions to the field. This new breed of scholar led to a shift in how social movements were conceptualized. No longer were they viewed as disorganized and spontaneous actions of likeminded individuals. The change came in 
the 1970's and 1980's, with a new viewpoint that was critical of theorizing about social movements using a collective behavior analysis, and instead focuses on how social movements obtain and utilize resources (Freeman \& Johnson, 1999).

Resource mobilization "[e]xamines the variety of resources that must be mobilized, the linkages of social movements to other groups, the dependence of movements upon external support for success, and the tactics used by authorities to control or incorporate movements" (McCarthy, 1977, p. 1213). Mostly the theory focuses on the mobilization of resources within movements, and how the state may block, inhibit, or otherwise interact with mobilization efforts (Morris \& Mueller, 1992). Resource mobilization looks at the effectiveness of the movement itself and its ability to garner resources, unlike collective behavior analysis, which focuses its attention on individuals and their motivations for participating (Eyerman \& Jamison, 1991).

One way that resource mobilization looks at participation is by considering the tendency for some to do a substantial amount of work to get the movement underway and remaining viable, while others contribute less but still enjoy the fruits of such participation, thereby being granted a "free-ride" (Tarrow, 1998). This leads to an uneven distribution of work and effort, on the part of participants, and jeopardizes the group. This theory, places emphasis on individual action and personal incentive, and emphasizes the effectiveness of mobilization efforts.

Such a view failed to adequately address the protest activities of the 1960's where people were advocating and fighting for causes that did not affect them personally. According to RM movements are carried out by social movement organizations (SMO's), 
that is, highly effective and well maintained organizations that organize and execute the movement. This provided a more organized explanation for how social movements are able to persist in the face of individual levels of involvement, thereby addressing the freerider problem. (Eyerman \& Jamison, 1991).

This shift of focus from individual motivation and involvement to effectiveness and organization of resources was not received well by social movement scholars in the 60's and 70's, because of the lack of emphasis on individual purpose and passion. Additionally, this new theory used terms and language from economics to describe processes within movements, which again failed to acknowledge human and individual motivations (Tarrow, 1998).

\section{Conflict Resolution Literature}

Much of the Conflict Resolution (CR) literature on protest activities is based in nonviolence and civil disobedience. Since Conflict Resolution is a multi-disciplinary field, many of the ideas and concepts from Sociology and Political Science are applicable as well. CR scholars touch on issues of social conflict, bringing in some concepts from Psychology. There is a gap in the Conflict Resolution literature when discussing social movements, and the behavior of participants.

The CR literature references collective behavior and resource mobilization (Kreisberg, 2012). However, conflict theory within Conflict Resolution sees the rise of social movements as founded in the belief, by participants, that their actions can bring about change. In democracies, a majority can organize to get the attention of the state in order to bring about change. Although democratic institutions are organized so as to give 
people channels outside of demonstration or protest, to foment change, these institutions can fail, necessitating recourse to acts of civil disobedience (Sharp, 1980). People engage in such actions because they are suffering harm and believe their participation can improve their circumstances. Conversely, although conditions under which people live may be egregious, if they believe that they are unable to change their circumstances they will not participate in protest activities or other acts of civil disobedience, and view such attempts as futile (Kriesberg, 2012).

Additionally, participants must believe either that their position is strong, or at least that their adversary's position is weaker, in order to initiate the conflict to bring about social change (Kriesberg, 2007). In this sense, conflict is vital for change, and actors will not engage in such activities if they believe they will be unable to alter their circumstances. Instead the status quo will remain, the conflict will not surface, and neither will opportunity for a change circumstances (Kriesberg, 2012).

\section{Occupy}

Occupy Wall Street. Occupy Wall Street (OWS) came about when the Canadian magazine Adbusters issued a call to action in its July issue, encouraging people to camp out on Wall Street in New York City for a short, but undetermined, span of time. Originally the purpose of the action was to get the president to set up a commission to investigate the influence of money in politics (Culture Jammers, 2011). This call to

action in July provided the initial momentum leading up to September $17^{\text {th }}$ - the first day of occupation. 
The early days of organizing were fraught with confusion, as an action like this had not previously been planned in the United States, on such a scale, in modern times. Organizers consisted of a mix of students and activists from around the world, with varying levels of experience (Taylor \& Gessen, 2011). It should be noted as well, that these pioneers included those who identify as anarchists- a controversial group within the movement still. The original site chosen for the encampment was in front of the charging bull that has come to represent Wall Street. However, on the day of action the New York police department set up barricades preventing assembly, a restriction on speech that was permitted because the location, 1 Chase Plaza, is public property and permits granted by the city are required to protest in such spaces. The protesters ended up at Zuccotti Park, which is privately owned property, and set up camp (Batchelor, 2011).

During the early days of Occupy the New York Police Department (NYPD) came out in large numbers and there were frequent clashes between protesters and police. The NYPD used methods such as kettling, surrounding protesters in a way that there is only one direction for them to exit or no exit at all from an area. Another tactic was pepper spraying protesters for blocking traffic, and causing the closure of city streets during the action on the $24^{\text {th }}$, and mass arrests of more than 700 people on the Brooklyn Bridge on October $1^{\text {st }}$, for impeding vehicle traffic (Baker, Moynihan, \& Nir, 2011; Knuckey, Glenn, \& MacLean, 2012). Some saw the actions of the NYPD as excessive, which worked to increase public support for the Occupy movement. At this time, the trend seemed to be that the more excessive the police were the more public favor the protesters garnered. An in-depth study of the use of force was completed by Fordham University 
and New York University law schools and, despite a finding of systematic repression of Occupy protesters by the NYPD and police in four other American cities, there has been little or no disciplinary action against police (Knuckey Glenn \& MacLean, 2012).

Factors leading to Occupy Wall Street. A combination of social, economic, and political factors created a fertile environment for the rise of Occupy Wall Street. The most commonly acknowledged, and perhaps most obvious, precursors to OWS are the events surrounding Arab Spring. The sheer power of the mass mobilization and direct action participation of citizens, during these protests, served as an example and model for the potential of mass mobilization to lead to political change. There was a hopeful feeling around this time, as country after country overthrew dictators, some nonviolently. It seems that from these actions sprang a sort of "if they can do it why can't we?" mentality that helped spark the fire that became Occupy.

Political factors. Arab Spring was accompanied by other national actions that led to the occupation of Wall Street, most notably the occupation of the state capitol in Wisconsin and Bloombergville (Sledge, 2011; Vorpahl, 2012). In Wisconsin, starting in February 2011 public sector workers began a series of protests, eventually resulting in a 24 hour occupation of Wisconsin state capitol, which closely resembled the camps of OWS. There were not as many reports of the nature of local law enforcement's response was; this is likely due to the fact that a majority of those protesting were members of unions, including police unions and some of the participants were even officers themselves. 
Later that same year, about a month before the call to action by Adbusters, a group protesting budget cuts set up camp outside of New York City Hall. This action was preceded by a series of public employee layoffs and cuts to social programs. The camp set up by protesters became known as Bloombergville- a combination of the name of the New York City mayor Michael Bloomberg and the encampments of the Great Depression known as Hooverville. The camps at Bloombergville, were similar to the camps that were set up during the Occupy movement. Bloombergville is where we first see the General Assembly, which played a significant role in the horizontal organization of OWS and served as a means of consensus organizing (Democracy NOW; Bloombergville Now!, 2011).

Other factors that contributed to the general malaise in American politics at this time include disappointment with the presidency of Barack Obama and the rise of Wikileaks. With the election of the $44^{\text {th }}$ president came political capital, along with an overflow of hope that circumstances in the United States would take a drastic shift from the social and economic policies of the former administration. Unfortunately, for many Americans, much of the hope that was brought by the Obama administration never manifested in a tangible way, leaving many feeling disappointed and let down (Vielkind, 2012). It is this feeling along with the Wikileaks release of classified documents (approximately one year before OWS) that topped off the political events that led to Occupy (Associated Press, 2011).

Economic factors. The state of the world economy also helped to create an atmosphere for OWS to flourish. It is my contention that a downward economic spiral 
and widespread corporate corruption and abuse were precipitated by the terrorist attacks in the United States on September 11, 2001. This is based on the teachings of Milton Friedman, that crisis creates a unique opportunity for privatization and a shift in the control of markets (Klein, 2008). During times of crisis, people are less apt to resist, or question, market and capital and therefore free market ideas must be swiftly imposed. According to Friedman, those ideas must be ready to implement the moment disaster hits and that implementation must occur quickly (Klein, 2008). When 9/11 happened the United States was able to justify bringing our brand of democracy to new markets throughout the world. With this expansion of trade and the opening up of markets came cheaper labor out of country. As our interest in freedom and democracy grew, so did our war machine and the outsourcing of its maintenance. At this time many government and private jobs were outsourced, causing economic growth in the United States to be stagnant and those with jobs to lose them (Klein, 2008).

At the time Occupy came about, the US economy was in a similar state as it was during the Great Depression. Unemployment was up and the gap between the very rich and the rest of the population was increasing. In 2007, preceding the economic crash, the income of the top $0.1 \%$ grew more than it ever had before. Not only was the gap between the rich and the poor getting wider but the gap between the rich and the super rich widened as well. Krugman and Wells (2012) argue that this economic inequality correlates to political polarization. By looking at a well known study, in which congressional roll call votes were mapped according to party, the authors conclude that politicians consistently vote along party lines, which in turn polarizes the parties 
(McCarty, Poole, \& Rosenthal, 2008). This polarization, they believe, made it difficult for president Obama to create jobs in the face of Republican opposition. Additionally, such infighting created an environment hostile to the political and economic reform needed to avoid the economic collapse of 2008.

Occupy Portland. Occupy Portland started off nonviolent, and claimed to be acting in solidarity with Occupy Wall Street. ("Occupy Portland," n.d.) OPDX began on October $6^{\text {th }} 2011$, roughly two and a half weeks after OWS. The OPDX encampment came about around the same time as occupations in most other major cities across the United States. The actual occupation of Lownsdale and Chapman Square in downtown Portland lasted approximately five weeks; the campers were evicted by Portland Police on November $13^{\text {th }} 2011$.

A likely influence on the composition and population of OPDX is the disproportionately high unemployment rate in Oregon following the 2008 economic collapse. From April 2008 to April 2009 unemployment in Oregon saw a 6\% increase, the highest of any other state for that time period, making Oregon the state with the second highest unemployment rate of any other state. Michigan came in first with a 13.2\% unemployment rate (Bureau of Labor Statistics).

The decision making process at Occupy Portland is based on consensus, and the process takes place during General Assemblies. According to the website for Occupy Portland "[t]he General Assembly is a gathering of people committed to making decisions by working towards a collective agreement or 'consensus.' It aims to facilitate discussion and getting to know one another, in order to establish common ground and 
encourage compromise through mutual recognition of difference." The process begins with a proposal, and if there is consensus and no objection to the proposal, it passes and direct action can begin. If there is no immediate consensus than participants deliberate, there is an opportunity for modified proposals, or those who proposed can revise the proposal and resubmit it at the following General Assembly. If none of these events occur, a vote is taken and if there is a $66 \%$ majority vote in favor, then the proposal passes.

Some other noteworthy characteristics of Occupy Portland include the horizontal leadership structure and the level of involvement of participants. The Occupy movement generally and Occupy Portland specifically pride themselves on organizing according to a horizontal leadership structure. Therefore, although there are people who take certain roles, some perhaps more visible than others, there are no official leaders. All of the major decisions are made by consensus; no single person ever makes decisions alone that would significantly affect the movement.

The first GA in Portland occurred two weeks before the actual march and occupation. At that time people separated into groups and decided what role they would play during the march and later encampment. The march took place on October $6^{\text {th }}, 2011$ at which time organizers were expecting around two thousand people. These expectations were far exceeded, and by day's end, the crowd had swelled to over 10,000. In the early life of the protest and occupation the police relationship with occupiers was relatively peaceful and there were few unpleasant interactions. OPDX had a team of people whose job was to liaise between OPDX and police. However, as time went on 
that group disbanded and protester-police relations became strained. In an early attempt to try and avoid confrontation with police and maintain peace, OPDX decided to set up camp at Chapman Square because it is federally owned property and therefore imposes fewer restrictions on speech.

Encampment. Once protesters took over the parks they quickly set up camps and these spaces became microcosms of small cities. The camp set up by OPDX was similar to other camps around the world because it provided for the basic needs of occupiers having: a kitchen, library, sanitation, medical area, media space, and art space. In addition, the Portland camp also had a children's camp, a community garden, a café, and a relaxation tent. The OPDX camp was divided by Main Street and the two parksChapman Square Park and Lownsdale Square Park—which became known as Alpha and Beta camp, respectively. Much of the buzz and energy was located in Alpha camp, along with the kitchen and café. The Beta camp was home to the library, medical, art, legal, and Food Not Bombs tents. Beta camp was much quieter and more family-friendly than Alpha camp (Johnston, 2011).

An issue that came up at OPDX and other encampments around the country was how to engage with the homeless and mentally ill population. The free food, readily available community and medical attention attracted many of those who were on the losing end of the economic oppression the occupy movement came to signify. This created a very unique quandary for organizers, and remains one of the biggest debates in the movement. The question became how to serve and represent those who are destitute and at the lower end of the economic spectrum and still appeal to the broader population, 
who may be turned off by images of those who are homeless, mentally ill, or addicted at the camps.

Public participation. Much like the OWS movement, OPDX garnered a lot of support from the public at large. The number of people camping out was far less than the number of those who support the movement. This is evident by attendance at actions. For example, November 172011 (N17), the celebration of the movement's 60-day anniversary, was attended by over 5,000 people, while the encampment itself was facing eviction just four days prior.

Current state of OPDX. The current state of OPDX is unclear. The group seems to be experiencing the trial and error experiences that accompany the development of most organizations. Affinity groups that were formed during the initial occupation are continuing their work, and much of what is being done centers on community building. The group currently has an office in Southeast Portland, which seems to be a place people can connect and affinity groups can receive support.

Overall, OPDX received a lot of support from the citizens of Portland. In many instances the number of people who showed up exceeded organizers' most optimistic estimates. It seems that there is something in this movement that resonated with people, something that was able to bring Portlanders out of their homes and into the cold, in some instances all night. My goal is to find out the principal reasons for participant involvement in Occupy Portland. 


\section{Chapter 3: Methodology}

\section{The Approach}

I explored the principal reasons for participant involvement in Occupy Portland using a grounded theory approach. "The grounded theory approach is a general methodology of analysis linked with data collection that uses a systemically applied set of methods to generate an inductive theory about a substantive area" (Glaser, 1992, p. 16). This methodological approach allowed me to answer the question, and build a theory to be tested in later work. Instead of further developing an already established theory based on why I think people participated, I chose to take a grounded theory approach and develop a theory based on the perspective of those who participated in OPDX (Churchill, Clark, Prochaska-Cue, Creswell, \& Ontai-Grzebik, 2007).

However, commentators and scholars warn that the use of grounded theory runs the risk of developing a hypothesis that has already been tested or finding that the phenomenon explored can already be explained by a previously developed theory. This being so, it seems that if this occurs in my study my research would act to further substantiate the already developed theory. Since there has not been much previous scholarship on Occupy generally and no academic scholarship on Occupy Portland, my study, if it fails to present a new theory, would show that current theories continue to be relevant.

\section{Participants}

I interviewed individuals who I have come to know through personal involvement in OPDX or through connections I have made in other areas such as the classroom or 
through people with whom I am acquainted. These sources proved fruitful enough for me to perform substantial interviews so that I could reach a level of saturation.

The goal of Occupy to represent the $99 \%$ posed a difficulty in determining criteria for who participants are for the purposes of this study. One of the issues I considered was whether to include those who are a part of the $99 \%$ but chose not to camp out or become involved in any of the actions, such as protests or sit-ins. Should attendance at the General Assembly be required to be counted as a participant or would attendance at protests alone qualify?

Finally, I decided that a participant for purposes of this study must meet four criteria. First I will consider, as a participant, anybody who defined themselves as such. In coming to this decision I took into account that there may be people who want to attend protests and General Assemblies but are unable to attend because of issues of child care, physical ability, and lack of access to transportation, etc. They may contribute to the movement in other ways that are difficult to quantify or articulate, such as initiating conversation, or dissemination of information. Secondly, participants must be present at the initial march on October $6^{\text {th }}$ presence at the march is the criteria here, not necessarily involvement. Thirdly, subjects must have attended at least two actions thereafter, whether they are General Assemblies, rallies, protests, or any other related activities. Finally, I sought out people with varying levels of participation. I did not want all of my informants to have the same or similar levels of involvement because a cross section of level of participation may provide different insights into reasons for participation. Please see Appendix $\mathrm{C}$ for more information on participants. 


\section{Procedures}

The interviews were conducted using a semi-structured series of open-ended questions; this allowed the conversation to unfold naturally and intuitively. I contacted the participants via email or text message, and asked them if they would like to participate in a study about Occupy Portland. If they answered in the affirmative I asked them what location and time was convenient for them. Some participants wanted to meet in a coffee shop, one asked me to her house, and one came to my house. Once we both arrived at the meeting place I asked them to read over and sign the consent form and offered them a copy. I would then ask the participant's permission to record our conversation, and begin reading off my list of questions. Many of the answers to questions required follow up questions, which I asked, and where a participant's answer was unclear or vague I followed up with clarifying questions.

This approach was taken in order to provide participants with enough flexibility, time, and space to explain their motivations and reasons for involvement. Flexibility was important in data gathering, because, in connection with the grounded theory approach, I wanted to give informants adequate opportunity to convey their perspectives and fully communicate their reasons for involvement. In some cases a question seemed relevant and helpful to answer my research inquiry, but may not have been on my list; however because of the grounded theory approach I was able to ask it anyway. Additionally, there were some circumstances and situations where it was necessary for me to ask clarifying and follow-up questions that I had not previously written down. This approach is in line 
with the emergent nature of qualitative research, and requires improvisation on the part of the researcher when conducting an interview.

Additionally, it is an important characteristic of qualitative research that the data be gathered in a natural setting instead of a lab or other contrived situation. The face-toface interview is a credible alternative to sending out a form or other instrument for informants to be complete, as is often used in qualitative data gathering (Creswell, 2009).

I recorded each interview using a mechanical recording device, and saved each interview on separate sides of mini tapes for transcription. I took virtually no notes, but jotted down an idea or concept on occasion in order to remember a connection that had occurred to me while the informant was speaking. Mostly I focused on being present for the interview and did not worry about taking notes or trying to memorize exactly what someone was saying.

After each interview I went home or to a different coffee shop than where the interview occurred and made notes of my personal impressions or ideas from the interview itself. Within at most three days following the interview I fully transcribed it, listening to the tape and typing out each word spoken. I then played back the tape at least two more times to make any corrections necessary and fix any slight mistakes I may have made in typing or mishearing. Following this process I rewound the tape for reuse.

Throughout the data gathering process I maintained both field notes and expanded field notes on my computer which is backed up by a hard drive. The files were stored behind and password protection. The written transcript was created solely by me and is a verbatim representation of the interviews. I created pseudonyms for each participant, I 
gave each an opportunity to choose his or her own pseudonym and for those that declined I created one for them. I put the list of the corresponding names to each pseudonym in a password protected file on a password protected computer. Additionally, after each transcript was complete I went through each and removed any identifying features.

Once all of the interviews and transcriptions were complete I went back and began to do coding. I went through each transcript and coded section by section. Each section contained at least one line and in some cases two or three. The length of section was determined by the idea conveyed and how succinctly it could be summarized in the margins. This varied by participant, for example, some spoke using few pauses and had many descriptive words, their sections tended to be bigger. Others were more succinct and took many pauses and their sections tended to be smaller, perhaps one line. I did not do line by line coding, as is sometimes suggested in lieu of word by word coding because of time constraints; however themes quickly emerged by using the section by section approach. After this, I went back through and looked at what emerged and made a separate list of all of the themes that came up for each interview. I then categorized the topics and focused on those which appeared to illuminate my question.

\section{Bracketing}

Starks and Trinidad (2007) note that the researcher "must be honest and vigilant about her own perspective, pre-existing thoughts and beliefs, and developing hypotheses . . engage in the self-reflective process of "bracketing', whereby they recognize and set aside (but do not abandon) their a priori knowledge and assumptions, with the analytic goal of attending to the participants' accounts with an open mind" (p. 1376). 
Before I decided to research motivations for participating in Occupy I had attended Occupy events and had encountered, and even befriended many of those who became the research participants during this time. Therefore a previous relationship between participant and researcher had been established. The participants knew of the researcher's interest and involvement in Occupy. During the interview process, however, the researcher was aware of her own bias and bracketed those feelings. Bracketing requires reflexivity on the part of the researcher, and awareness of her triggers and biases (Ahern, 1999). Here, the researcher kept in mind the potential for bias, and what areas might be triggering. This process was made easier by the time which had elapsed between the experiences discussed in the "Researcher's Stance" chapter, the Occupy Portland encampment, and the interviews. There was ample time for me to reflect and gain some distance from these events. 


\section{Chapter 4: Findings- Capitalism and Corporations}

The first, and perhaps most obvious, reason why participants went to actions associated with Occupy Portland was their anger and frustration over corporate abuse and capitalism. Many of the images and much of the language associated with both OPDX and OWS reflect distaste for corporate dominance. The quintessential image of OWS is a ballerina on top of the bull that stands in front of the New York Stock Exchange on Wall Street. Considering such anger and frustration, this finding is not a surprise, however, in light of the many issues advocated for, banners flown, and causes represented, it was surprising that most participants still believed that their causes had roots in corporate abuse and unfettered capitalism. Brian had never been to a protest and was not involved in activism prior to his participation in OPDX, but the perceived corporate abuse was enough to compel him to participate.

It was... one of those things where I was... reading a lot about corruption in the system and it just happened to come along at the perfect time I remember having a discussion with one of my friends like we need to start some type of movement... that kind of captures... all of the problems that are happening right now then Occupy Wall Street came along, that seemed to be... right up my alley what I wanted to it was addressing the issues I had... there are a lot of issues Occupy encapsulates --- a lot of peoples issues and problems, for me personally it was really for... my issues with, you know, corporate control and our democratic system and the repercussions from the Wall Street bail out.

In his interview, Brian stated that he himself experienced no personal negative

effects from the issues he stated above. Although he did not see any of those issues as affecting him personally, he was still angry and this anger drove him to participate. Further on in his interview he referred to a sense of fairness and justice and said he was angry about corporate abuse, which leads to a conclusion that the principles that brought 
him to protest were based in a feeling or belief outside of him. He stated fairness and justice as some of the issues that were important to him and that lead to his anger and eventual involvement in OPDX.

Another noteworthy feature of these findings is the connection participants made between corporate abuse and various other issues. Brian, for example, saw the Wall Street bailout as connected to corporate control and weakness in our democratic system. Indeed this is a theme throughout many of the interviews - the connection between corporations and the particular issues or social problems that brought people to participate.

One great strength and weakness of Occupy was the amorphous nature of it. There was not one issue in particular that Occupy took up, nor was there a stated goal, instead it was a conglomeration of many issues under one banner. Nowhere is this more salient than in the issues stemming from participants' perceived abuse by corporations in the capitalist system. Participants in this study saw themselves as affected in different ways, some felt a burden to participate others were angry, and accordingly have different reasons for attending Occupy actions. The fact that Occupy was anti-corporate at its core but diffuse has lead some people to question the legitimacy of Occupy. For others this was a positive feature of Occupy, because it allowed for those who advocate for causes that are seemingly unrelated to all participate under a single banner. The great majority, though, felt that a significant feature of Occupy was the connection it made between our current economic state and capitalism. 
In the following section, I will discuss issues related to corporate dominance and capitalism that related to participation in OPDX. As with many protest activities and activism in general, the impetus for participation is nuanced, and this is by no means meant to be an exhaustive discussion of the relationship between corporate domination and participation in OPDX. I merely intend to touch on the topics that seem to be most salient in public discussion and that were mentioned by participants in this study in particular. These injustices can be divided into two categories according to participant accounts, those that occur domestically and those that occur abroad.

\section{Domestic}

Bank bailout. An issue that emerged repeatedly in interviews was anger over the 2008 bailouts of major banks. This topic was usually the first to surface when I asked people why they participated. There is a sense that the tone and timing of Occupy coincided with these bailouts and the effects of the foreclosure crisis, which is inextricably linked to the bailout. One participant, Sarah, spoke of the momentum for activism created by the bailouts.

...if you think back during the time that was going on....ight after the bailout and everything.... you just really felt that pressure and you knew that everyone else was feeling it you know.... people were ...overwhelmed and ... I'm that type of person who will get involved.... so it's just like let's do it. People coming together. Let's do it.

During the time of the encampment, OPDX marches centered on downtown banks. Additionally, a largely successful campaign was orchestrated for people to move their money from major banks, such as Bank of America, Chase, or US Bank, into smaller local banks and credit unions. 
An interesting theme apparent from the interviews was an acute sense of anger and frustration about the bailouts. Though none of the individuals interviewed said they were directly personally affected by the bailout. Many felt a connection or resonance with issues associated with Occupy. The element of the bailout that seems to have the most impact on participants was that the measures to save big banks violated a sense of fairness and justice. One participant even went so far as to say that the bailouts, which indirectly involved taxpayers and citizens, put the whole democratic system at risk. What is significant here is that this sense of fairness and justice was so strong that it caused enough anger and outrage to get people to participate in Occupy actions.

Student debt. Two participants in particular said that student debt and the inability for people to pay back their loans is what brought them to participate. Indeed, this domestic issue is loosely related to the banking crisis, but I found it significant that this was brought up in such a strong way. Additionally, while most people did not see themselves as directly affected by the bank bailouts or the foreclosure crisis, those who referred to the student debt crisis felt a direct connection to this issue. . People are unable to pay for school or pay back their student loans because of high unemployment rates and low wages. One participant, Tedd, said that Occupy resonated with him because of his future prospects in today's economy.

... as a poor graduate student who is running away from his loans, and trying to get credentialed enough to compete in a market that is flooded with young adults with advanced degrees I see my options dwindling... and my place financially within this system not as secure and that's troubling. I don't want to have to participate in that sort of structure, but we kind of have to unless we work to change it, which could take a very long time. So... revolution could be... the switch, and that is kind of a naïve, ideal, view- that it will just happen, but you 
hope for it, and when you see something like this happen it attracts attention you know.

The inability to pay back loans in light of the current economic conditions was an impetus for many to attend Occupy events, so also were the conditions surrounding the repayment of the loans themselves. Even just a quick glance at the tumblr website associated with Occupy, weaarethe99percent.tumblr.com, shows that people are taking extreme measures to meet the burden of paying back student loans. The website was designed so that those claiming to be a part of the $99 \%$ might give a brief summary of the economic woes they are experiencing. Each person featured, writes down on a piece of paper, their story and takes a picture of the paper and sends it to the website, which publishes the pictures on a blog. Student debt is an issue that emerges repeatedly in these postings.

Most people going to college for the first time or going back to school are doing so to raise their standard of living, which should, theoretically, put them in a position to be able to pay back their college loans. The belief that those who graduate with a bachelor's degree have more access to higher paying jobs is not unfounded, wages and earnings for those with a college degree are substantially more than those without a degree, and by 2009 those with a degree earned $84 \%$ more than those without a degree (Leberstein \& Christman, 2012). However, although those with a college degree make more money, tuition and related fees at public universities have risen by $130 \%$ over the past 20 years, a cost borne by recent graduates (Leberstein \& Christman, 2012).

The result of higher tuition rates coupled with increasingly grim job prospects is that people have to go to extreme lengths to pay back their student loans. According to 
American Student Assistance (2013), a non-profit non-partisan organization designed to help students with their loan issues, "[a]s of Quarter 1 in 2012, the average student loan balance for all age groups is $\$ 24,301$. About one-quarter of borrowers owe more than $\$ 28,000 ; 10 \%$ of borrowers owe more than $\$ 54,000 ; 3 \%$ owe more than $\$ 100,000$; and less than $1 \%$, or 167,000 people, owe more than $\$ 200,000$.”

These circumstances leave more and more people with crushing debt, and helped make student loan debt one of the primary issues that angered people enough to participate in Occupy. OPDX led a rally and march protesting the crushing cost of student loans in which students and faculty alike participated (Saker, 2011). The student loan debt crisis and the circumstances surrounding repayment was what drew Bobby to OPDX.

Occupy student debt-- I think that's... really insane the way the whole system is set up around education and financing education and... and what's available and who gets to go to school and who doesn't... that was really big for-- big on my list because, you know, I have... tons of student debt already and it was... ridiculous... it's ridiculous that... people have to... live in their car to pay back student debt and... I just think that some of it is very unreasonable and... almost inhumane... I think if you borrow money you need to pay it back but not at the cost of... cutting off your arm or not being able to go to the doctor if you have medical stuff, so that was something I was really interested in seeing what other people thought...

This was Bobby's response when asked if she had any personal connection to OPDX. She connected with Occupy here, because she saw the student loan debt crisis as a systemic problem rather than an individual problem. Bobby's outrage at the substandard conditions that people experience in order to pay back their loans along with 
her own debt brought her to Occupy to seek systemic solutions and ideas for the student loan debt crisis.

Additional Themes. In addition to the above, participants mentioned various other reasons for attending OPDX. All of the issues that were mentioned, informants connect back to perceived failures of our capitalist and democratic system. Tiffany, who was a participant in my study, saw her work with food security as directly linked to the capitalism and some of the systemic issues being addressed.

yeah I think originally the people that came out to sleep at Zucotti were... specifically anti capitalist and were very clear on their targeting, which was... the banking system... [and] corporations... in ... serious coordination with our government, all working together to screw over the average person... I think that was very clear and that's exactly...the message that I had been relaying in my experience with food security and food sovereignty fights.

Similar to the comment from Bobby about student debt, Tiffany also saw the primary issues that brought her to participate as having roots in a flawed system. Tiffany had traveled around the western hemisphere doing work and participating in actions to promote food security and found that, while creating self sustaining organic farms in one region was helpful for that community such actions could not effecting a systemic change. Coming to Occupy, for her, was an opportunity to create change on a larger scale. In her own words Tiffany describes this experience,

I started farming organically and I was...trying to figure out what it looks like to create solution and realizing that...regardless of how many... seeds I plant the larger systemic problems...need to be...tackled and pointed out in a major way and that's what I saw Occupy doing.

Another issue that contributed to participants' attendance at OPDX was the mortgage crisis. Banks and lenders had overestimated their ability to cover loans and had 
given loans to people who were unable to repay them. The inability for people to pay their mortgage forced banks to foreclose, in large numbers, which caused hundreds of thousands Americans to be uprooted. Nobody I interviewed had to leave their home because of the foreclosure crisis.

A theme that seemed to be present in many of the conversations I had with participants, and referred to previously in this section, is the general feeling on the part of Occupy attendees of widespread crony capitalism. It was not the bailout of the banks in and of itself or the hundreds of thousands of people who lost their homes during the foreclosure crisis alone that enraged people enough that they felt compelled to protest. What I found very interesting was that not one of the participants in any of the discussions named an individual as being responsible for the corruption, nor even a group of individuals. Most everyone that listed corruption as the reason for their attendance, pointed to the system. Indeed there was a rather large contingent of people who attended Occupy actions that resisted the vilification of any one individual or group of individuals as being responsible for the corruption that occurred. .

\section{Global}

Some participants saw their role in OPDX as representing those from other countries who are affected by American capitalism and consumerism. Mostly they named poverty and issues associated with poverty abroad as reasons for their involvement. It seemed that these participants felt responsible for actions taken by the United States that contribute to suffering or poverty abroad. One participant, when asked what her main reason for coming to OPDX was said: 
widespread poverty, it was mostly the poverty that I saw, or perceived, in other countries, in Africa mostly, in parts of Asia, and South America... that were really disturbing to me, that I perceived were a byproduct of American capitalism, and consumerism, and ignorance... So I wanted to somehow help America get on track to righting the wrongs and balancing things so that other people across the planet could be experiencing peace and full bellies.

Another factor relating to American behavior abroad that brought people to

Occupy was the actions of international economic such as the World Bank, IMF, and NAFTA. What is interesting here is the connection between local action and international institutions. People felt compelled to protect, or advocate for, those abroad who might be affected by American actions. Some took this obligation very personally. Tiffany for example said that her primary reason for attending Occupy was related to international issues and the participation of the United States.

when I traveled when I traveled down to Latin America I got a chance to witness firsthand what happens, with not only our tax dollars with regards to like where they end up going, you know from the IMF and World Bank, and... development in third world countries or... what corporations do to... create this globalized food system and ... NAFTA, and all the trading systems that have been established you know it screws everyone over including myself, and if anything I am one of the more privileged people in the situation so... knowing that... I carry the burden of having to act because I know it's wrong. I would say that is definitely the way I have been affected by like wanting to participate.

What is reflected above is another reoccurring theme, the connection between government and corporations. Even the fact that the World Bank, comprised of quasipublic entities, was mentioned in the same breath as NAFTA and the IMF and government supported institutions, speaks to the sense that, in the mind of Tiffany, they are one and the same. There is a rich history of activism confronting globalization in the United States, the most memorable of which is the 1999 protest in Seattle against the WTO. 
It is clear than that people felt angry, upset, or frustrated because of the bailouts and other actions taken by corporate America. They saw OPDX as a place where they could take these emotions. Additionally, OPDX provided participants with a place where they could connect with other people who had similar feelings and beliefs. This feature allowed people to express themselves freely, where previously they may have felt their anger did not have an audience or they were afraid to express distrust of government. 


\section{Chapter 5: Findings- Large Scale Mobilized Revolution}

While the desire for change and reform of our economic system was a significant factor in bringing people to participate in OPDX, so was the popularity Occupy itself. In Portland especially, there are protests and opportunities for activism regularly. OPDX was not an anomaly in the issues it addressed. From the local to the national to the international, there are opportunities to become involved at all levels. The feature about OPDX that attracted people who were advocating for those issues that were otherwise often and frequently represented by smaller scale actions in Portland, was the scale and capacity of Occupy.

At its peak, Occupy Wall Street was appearing in the news almost every day, and the momentum created by protests and controversial interactions with police along with the increasing number of camps nationwide created momentum, which many could not resist. This phenomenon, and the almost irresistible urge to be a part of Occupy, is reflected by my participants as well. Some participated because they thought that Occupy was leading to the revolution that they believed was so needed in the United States. Others attended simply because they were hopeful that Occupy would result in some social change. Still others were reluctant at first but once camps started popping up throughout the world they became enthralled and decided to participate.

\section{Size and Organization}

Members of Occupy Wall Street first marched and camped out on September $17^{\text {th }}$ 2011, and quickly thereafter camps popped up across the nation and across the world. Almost every major city in the United States had an Occupy encampment, including Los 
Angeles, Chicago, Boston, Oakland, San Francisco, and Atlanta. Within the first month of OWS, camps continued to pop up and this trend, coupled with both mainstream and independent media attention, led some of the participants in OPDX to satisfy their curiosity by attending the actions in Portland. One participant in particular saw a video put out by OWS which tipped the scales of his curiosity and led him to participate. Felix did not go to the first march and encampment of OPDX, and in fact was highly critical of Occupy in the beginning but his mood quickly changed as Occupy grew;

after some time passed camps kind of spread around the country and like more and more news about them and things like that so I thought hmm I should be paying more attention so I started looking more umm... reading more about it and doing research and such...

Felix goes on to talk about his involvement with the library at OPDX and the radicalization he experienced as a result of his involvement with the movement. What is interesting is the transformation that he experienced. As mentioned previously he was critical of OPDX and almost contemptuous, but as the idea of Occupy started to spread he became curious and eventually got involved and underwent personal transformation. Arguably, this is one of the significant features of Occupy- it was widespread and had a very large following creating such a buzz and sparking curiosity that most people could no longer ignore it.

Others became less skeptical and cynical about Occupy once they saw it spread throughout the world. There is something about the size of the movement that made optimists out of those who questioned it at first. One participant, Tedd, actually went down to the camp because he was curious and thought it was weird, but became more involved after it began to spread, he describes his experience: 
[m]y involvement with Occupy Portland was mostly out of curiosity, more observing than...participating but participate to the extent that I was able to observe you know ... I was at the initial march and marched with them until they got back to Pioneer Square, hung around for a little bit, and then left .... Then I kind of just didn't do anything, I would... go visit the camps every once in a while and just...see what was going on, and observe, and just be like "oh this is weird." I was really cynical at first, but then...my cynicism started giving way once I saw how many other Occupys started sprouting up like all over the globe. Like ok this has got something behind it, there's definitely a sentiment that people are getting behind, and it's...causing momentum, which waned some of my cynicism...so I went to protests...

It is noteworthy that the size and momentum of Occupy caused Tedd to change his feelings. It seems that the appeal of Occupy to others made him believe in its viability which piqued his interest and provided a push for him to attend more protests. Because his cynicism waned once he saw more camps pop up around the world there appears to be a connection between the popularity of the camps and his feeling that Occupy is more than just a "weird" passing fad.

Watching others get involved and become excited about Occupy gave permission to some participants and therefore their own participation became a viable option. The effect of peer pressure here cannot be understated according to some participants. Once they saw initiative being taken on the part of their contemporaries, they were able to themselves participate and contribute to the movement. For Bobby in particular this factor was significant in her decision to attend Occupy actions:

seeing it all over the internet, all over Facebook, and then seeing...my peers be really involved was the biggest thing, because a big part of me not being involved with a lot of things because it's like if I'm not exposed-- it's like an out of sight out of mind kind of thing. As I saw... other people get involved and more psyched up then I was like oh... what is this about? 
To be sure, there were issues that Bobby felt strongly about and that she wanted to address and advocate for through Occupy. However, despite the level of passion she had or desire for change she felt, she did not become involved until she saw her contemporaries doing so, lending credence to the contention that participation was largely the result of the size and scale of the protests and popularity of the encampments OPDX, and for Bobby that was the deciding factor.

Some participants found power and strength in the size and organization of Occupy. The size gave them something bigger than themselves to look to and perhaps find safety or agency in joining and being a part of something that was not a part of them or that they did not have to themselves create, but was already created and operating outside of them. Sarah refers to this feeling here,

it was something bigger than you, you didn't have to organize it, it was organized for you already. All you had to do was show up on the day, and you were so interested and so riled up... from all the shit that was going on, all these people talking about all these problems, that you were like yeah fuck it yeah some shit is going to go down let's do it...

Here the draw and size of Occupy is also created by the buzz surrounding people's involvement, and how that was able to get others to come. What is noteworthy here is that the buzz leading up to the actual day of protest conveyed to Sarah that it would be large in size and gave her the belief that it would be something bigger than her.

\section{Revolution}

This point is made clearly by the answer Tiffany gave when I first asked why she decided to participate in Occupy Portland. Her answer was simply "The revolution's here, that's why." There was a feeling by many that Occupy was the precursor to a 
worldwide revolution. Indeed the related political events of the Arab Spring fed this belief as well. What is unclear however, is what people believed the revolution was going to lead to or what its purpose or focus was. One gets the sense that participants were looking for a change of any kind, whether it be a change in consciousness or economic structure and that is what Occupy represented to them.

There was one participant in particular, Sarah, who did not have affinity with any specific issue or cause but who attended because she felt that it was the beginning of a revolution. When I asked her what issue brought her to participate, or whether it was a collection of issues she stated that it was all of the issues.

For me what drew me in to...I mean you have to separate also like Portland Occupy from New York Occupy right so what drew me into Portland Occupy was I saw... I already saw what was going on in New York and it's like for me it wasn't like wow the one thing that I'm angry about is police brutality so I am going to go there and focus on that it wasn't about that for me it was about really participating in something that could have been a revolution you know we could have had a nationwide revolution, Occupy was everywhere there was an Occupy everywhere you know and it was... like we could have done it you know we all knew this could be it... that's why I went... that's why I tried to pull everyone in to be like yo whatever, you could change the world right now...

When questioned further, about specific issues or topics that she felt were represented by Occupy; Sarah continued to be resistant to tie herself to any one issue. She was certain to convey that she went to Occupy because of its mass revolutionary appeal. She wanted to be a part of history and perceived Occupy as her opportunity to do so. 


\section{Chapter 6: Findings- Personal Needs Fulfillment}

The most surprising, and perhaps telling, finding that I came upon during my research was that people were looking for certain needs to be fulfilled by coming to Occupy. This was the one feature that was common among all of the participants in this study. Each had a reason for coming to Occupy aside from only effecting change or seeing results outside of themselves. In the previous findings people's reasons for participating related to thoughts or ideas founded in Occupy itself. There they came to Occupy because of its widespread appeal; desire to be part of a large-scale global transformation/revolution; or because it became more attractive as it continued to grow. These findings refer to features outside of the individual, whereas this final category speaks to individual, internal needs that Occupy helped participants meet.

These reasons for participating range from a need for self expression to a desire for personal empowerment. Additionally, many participants mention feeling angry or enraged about the bank bailouts and other corporate abuses. They see Occupy as a place to bring this rage or attended Occupy because of this rage. They saw Occupy as a place to bring these emotions of frustrations and anger to share with others. Again, what is noteworthy is that this anger was not necessarily connected with a desire for change or plan of action. The empowerment that drew people to Occupy was related also to its size and mass appeal, those who were drawn to it for this reason wanted to feel like they mattered. Bobby talked about how Occupy made her feel empowered.

it seems like everybody else was doing action and so ... I wanted to do action, and it felt... kind of empowering like people were doing something with it instead of just talking about it, and so it was like if they can do it then I can do it and not like... I got... you know I wasn't...standing on top of a building or doing 
anything crazy like that, but it made me feel like maybe my opinion and my concerns could matter, if I took time to talk to other people about it.

Earlier Bobby talked about the size of Occupy and how that made it easier for her to get involved, the size seemed to play a role here as well in the sense that to her, many other people were involved and she wanted to be a part of that . Another significant feature of Bobby's statement is that she did not feel that her level of involvement mattered. She felt that she could only do so much, because she believed that she was not very well versed on the topics and not willing to risk arrest that her level of participation was inconsequential.

\section{Anger}

As mentioned above, some of the people that came to Occupy came because of their anger over the bank bailouts and other harm that, they perceived, was perpetrated by capitalism. They came looking for a place to channel and express their anger. Roxy was one of those participants who felt that OPDX provided her a space to do this. When I asked why she chose to participate she answered:

I had been learning a lot about corruption and capitalism and the government and sort of had a well of anger and resentment for the people at the top who were perpetuating this paradigm or who I perceived were perpetuating the paradigm and I wanted an outlet I guess to express that and to meet other people who were on a similar wavelength and to see what was out there what energy was alive

Roxy's anger was enough for her to be significantly involved in OPDX; she was the founder of the library at the camp and lived onsite for the duration of the encampment. Roxy’s decision to participate was not connected to any issue in particular. Additionally, she did not claim that she suffered any sort of personal harm as a result of 
the financial collapse. Her attendance at Occupy was based on factors mostly outside of her. Factors that caused a reaction, decidedly personal, of anger, that is internal. Roxy was also angry about the role of American capitalism in spreading poverty abroad. What is notable here is that Occupy was a safe place for her to bring this anger and that it provided her a space to express it to others. It is remarkable that she found no other societal institution or outlet for these feelings.

Another parson, like Roxy, who was angry at the economic situation, was Brian. He felt enraged by the bank bailout and felt like something needed to be done. Brian was mad and wanted a place to take these feelings, Occupy provided him with that place, and for him it encapsulated many of the issues he felt angry about.

well my personal... I guess my personal feelings towards umm corporations and politics especially here in the United States corporate control of the political system here and also the 2008 bailout and umm just seeing the repercussions from what happen with Wall Street when millions of people lost their homes umm was enough to make me mad, you know it was enough to make me mad and I think that is part of it you have to be kind of angry to be there and it was enough to make me mad, it was really one of those things where I was really reading a lot about corruption in the system and it just happen to come along at the perfect time I remember having a discussion with one of my friends like we need to start some type of movement... that kind of captures all of this all of the problems that are happening right now then Occupy Wall Street came along that seemed to be exactly what right up my alley what I wanted to it was addressing the issues I had

OPDX provided Brian with a place to bring his anger; Occupy was the embodiment of his feelings. There is a sense that Brian's anger had been building up from all that he was reading and learning about, and Occupy provided him a place to go with all his anger. For him, Occupy was the tangible manifestation of his frustration and anger. In a way he joined his personal anger with the collective protest. Validating and empowering; giving his anger voice and capacity to effect change. 


\section{Self-expression}

There was a sense in many of the interviews that people wanted a place where they could talk about things that were important to them, and voice their opinions. These individuals saw Occupy as providing a safe place to do so. The General Assembly provided individuals with an active audience and an equal voice, a circumstance they may have not previously experienced. Closely tied in with the empowerment that drew people to Occupy is the sense that they saw it as a venue for personal expression. Roxy saw this opportunity for self-expression as a principle of Occupy and this is something that drew her to OPDX.

that was enough like yeah enough is enough I don't know what enough is but I've had enough of something I've enough of being quiet and not saying anything and being afraid to speak up and... so I guess the value that attracted me was just a place to be heard and a place to have the people's voices amplified I guess the value would be expression... self expression.

Here the feature that Roxy identified of not being afraid showed that OPDX provided people with a feeling of safety because of the sheer numbers, and perhaps membership with those who are likeminded. Additionally, Roxy described the value that attracted her as being self expression and emphasized the reach of the number of people that made it to OPDX. What her interview makes clear is that self-expression requires an audience. Occupy provided the audience for Roxy and others to express themselves.

\section{Usefulness}

Occupy provided people with an opportunity to feel useful. Because of its widespread appeal and the number of issues that it covered, OPDX resonated with people from many areas of life and with a variety of talents. These talents were channeled 
through Occupy, and the potential for people to use their skills, Tiffany for example was good with computers so she helped post things on the website, for a cause that they found important was part of what drew people to OPDX and what kept them there as well.

Brian found this to be the case with his theater background

once I realized that there was a way that I could use my art to actually do something that I truly believed in... I hadn't felt that way in a while... using it in a sense that like I'm actually doing something... I'm actually using this to change minds, or getting people to feel something they hadn't felt before. Other than just you know making the Tempest as pretty as possible and bright and colorful you know

Others were less specific when referring to their skills and abilities, but still saw

OPDX as a place to use those in a way that they perceived as useful. Roxy summarizes this idea perfectly when she says "I wanted to serve in an environment where my skills and abilities would be umm... like... much needed." In this conversation she was referring to her privilege and how it allowed her to gain certain knowledge and competencies and was excited to come to Occupy as a place where the fruits of that privilege could be put to use in a way that she found to be fulfilling.

\section{Looking for meaning}

Similarly to what was referred to in the researcher's stance on the study, and alluded to in the previous findings many of the participants saw their personal history and family struggles as rooted in the topics addressed by OPDX. What seems to be common among participants is that whatever their personal feelings were, they viewed their participation in OPDX as a way to address their needs arising from the challenges they encounter. When asked whether she had a personal connection to Occupy Sarah responded: 
I mean shit happens to all of us you know what I mean like I grew up mostly raised by my grandparents single mom style and you know everyone has problems and we need to see those problems many of them in a wider picture... in

a... take a step back from it and see that it's like our issues are all the same and they're ruled over by the state you know

This response from Sarah was prompted by a question asking her if she felt any personal connection to Occupy. Although she had previously mentioned the bank bailouts and financial crisis as impetus for the momentum of Occupy, Sarah here refers back to the state. There seems to be a general sense among participants that the state and corporations are inextricably tied, as is revealed in findings here.

\section{Burden/Privilege}

There are a handful of people who participated in OPDX who came because they believed that it was their responsibility to participate. Such people felt that their privilege created an obligation for them to be a part of OPDX. Additionally, others felt compelled to participate because they felt that wrongs were occurring and that they were obligated to be a part of the solution. When I asked Tiffany whether any of the issues that Occupy addressed have affected her personally she says "I carry the burden of having to act because I know its wrong I would say that is definitely the way I have been affected by like wanting to participate."

\section{Connection}

Another internal need that drew people to Occupy was that they sought connection. People seemed to be feeling deep emotions associated with many of the issues connected to Occupy and wanted a place to share these emotions with others. Participants felt connected to others who were advocating for the same issues and wanted 
a space to meet likeminded individuals and share a common goal. Additionally, there were participants who came to Occupy because they saw others taking action and thought that if people they related to could participate in protest actions related to Occupy then so could they. Such an experience is what drew Felix to join OPDX. When explaining how he came to participate, Felix described the evolution that occurred in him from being completely turned off by the protests to looking on the OWS website and finding resources that resonated with him and stories that he related to,

the biggest thing for me was that they had several videos of different volunteers kind of explaining why they were doing what they were doing and what they thought about different stuff I remember one in particular I don't remember his name but he was basically my age he was a PhD student and he was like 'I should be working on my dissertation but I think this is really important' and it was interesting because around that time I was working on my own thesis and that was kind of fascinating for me he said several things that I could really relate to and so then I made the decision to go to the camp

This connection here that Felix felt was relationship, he felt connected to the $\mathrm{PhD}$ student in the video and formed relationship with this person he had never met. What is evident is that Felix was looking to understand what the appeal of OWS was, and in that search he stumbled across this video and found connection with the student featured. The connection was substantial enough to intrigue Felix to listen to the points made and draw him to participate in the encampment.

\section{Hope}

An underlying, and I think almost implied, feature of Occupy is hope. Generally speaking, people came to Occupy because they believed that it might lead to something better. As the movement got bigger even the most cynical and critical individuals became involved and expressed their hope, as was clearly the case with Felix and Tedd. 
Tedd described himself as a cynical person, and was very wary of Occupy at first but later became more involved. Even a self described cynic, he came to actions and the hope of change is what drew him there,

I'm very cynical [as a student]... we've kind of been exposed to seeing... the ills of the whole system you know... the tendency for it to... lead to the top and the way interest rates work... a top heavy system that will just never lapse and it just perpetuates inequality and so I am very cynical of capitalism and I am happy to see any group of people get together and sort of lampoon against it so that was probably my initial interest and just wanting to... wanting fundamental social change just wanting to see that happen was probably what attracted me initially.

In most of Tedd's interview he was critical of the purpose effectiveness and sustainability of Occupy in the present economic and political climate. However, skepticism aside, he participated in Occupy anyway, because he wanted change, and hoped that, as it grew in size and attraction, Occupy might provide for that possibility. 


\section{Chapter 7: Conclusions, Implications and Recommendations}

\section{Conclusion to the Findings}

Movement or moment. Some participants viewed Occupy Portland as the beginning of a social movement; others as a single moment in a larger movement. Mostly the literature on this topic is unclear. According to Tarrow's (1998) social movements are "those sequences of contentious politics that are based in underlying social networks and resonant collective action frames, and which develop the capacity to maintain sustained challenges against powerful opponents" (p. 2). Contentious politics are episodic, collective and public, encounters between those who are making claims and those who are the object of the claims, additional features are that (a) the government is a party to the claim by being a claimant or object to the claim or having some other involvement or interest, and (b) the claims would have an effect on the interests of at least one of the parties (McAdam, Tarrow, \& Tilly, 2001).

According to this definition, OPDX falls short of being a social movement because of its lack of a clear goal and clear target. The government is not one of the claimants for Occupy, because the protests have no goal. Therefore, the redress sought is not from government or anybody in particular. The second part of the definition of contentious politics is difficult to evaluate because there are many groups associated with Occupy and each has different reasons for participating in actions. As the above findings reflect, there is not one single goal or claim made by OPDX, or Occupy generally, therefore this element of the definition is almost impossible to evaluate. 
It is clear then, from the interviews conducted here, that OPDX is not itself a social movement, and is not part of a larger social movement as traditionally defined. This leaves the question of how to describe OPDX and other actions using the name "Occupy" as a descriptor. Some believe that Occupy is merely a meme, which is a cultural phenomenon that spreads among people in a culture; essentially it is a form of imitation. Still others describe Occupy as a moment that has come and gone, not to be repeated. One participant characterized OPDX specifically as a moment that is part of a lot of other activist work that happens in Portland. He even refers to the park where the Occupy encampment was located as having a rich history of activism.

Occupy and Collective Behavior. Parts of the findings confirm a collective behavior and parts diverge from such an interpretation. To begin with, Occupy was a spontaneous act in that it was not planned for a significant amount of time; between the first Adbusters call to action and the initial occupation of Wall Street only about two months passed. However, the spontaneity characterized by collective behavior was closely tied into the unpredictability of crowd behavior; a sort of mob mentality. Many of the participants interviewed said that they had felt angry about current events or that they had a specific issue that was addressed by Occupy Portland. Others joined because of the sheer size of actions associated with Occupy, and belief that it was the beginning of widespread revolutionary change. In this sense, there was a sort of mob mentality in that those who joined did so because of the momentum of the movement and its potential for effecting change even though the nature of the change or extent to which change needed to occur was unclear. 
OPDX had no specific stated goal. One can postulate though, on certain concessions that, if made by corporations, may have satiated those who participated in the actions. Given the various issues that brought people to participate in OPDX actions, it is difficult to point to a single goal. There seems to be general agreement that change is necessary, and even that change occurred to some degree or another. However, the specifics of that change are less clear. Some participants said that they believed that Occupy represented a shift in consciousness, others believed that it was the start of people rising up for a nonviolent revolution, still others hoped it would lead to accountability by bankers and others who participated in the 2008 financial crisis. Having a clear goal that all members agree upon is a significant feature of collective behavior, and the fact that OPDX does not state one disqualifies it from such an analysis. Specifically, the fact that participants did not gather or participate in OPDX for the same reason, means that the agreement or common purpose required for collective behavior is not present.

However, another key feature of collective behavior is that actors are protesting in response to a strain on the system or a change in social norms causing anger, frustration, or distress (Cohen, 1967). Strain on the system seems to be precisely the reason why people participated in OPDX. Whatever their specific issue was, whether it was worldwide poverty and globalization, or corporate abuse, or healthcare, people were frustrated and they felt that the system had failed to protect and provide for them. Further, they also believed that the system was unable to redress their grievances and therefore resorted to protest. 
Occupy and Resource Mobilization. Some of the underlying assumptions about collective behavior seem to have been present at the Occupy movement. For example, participants noted that some people were more involved and contributed more to Occupy actions than others. Scholars that wrote about resource mobilization had trouble seeing how protests were sustainable given the different levels of participation, with some people just riding the wave of protest and other's contributing significantly. They focused on social movement organizations, and other more mechanized and organized contributors to the movements.

In OPDX, participants spoke of varying levels of participation. They noted that those who maybe just showed up at the larger actions, but did not otherwise significantly contribute, did not seem to negatively affect protest activities or the sustainability of the camp. Additionally, OPDX was mostly self sustaining and relied very little on outside organizations, or social movement organizations. Therefore, resource mobilization cannot easily be applied to Occupy Portland.

Occupy and Social Movement Theory. Given these theories, and the fact that Occupy does not fit into any of them, it seems that perhaps a new frame is required. Old theories may have been relevant when used to analyze social movements and protest activities in the past, but as times change so must the frames we use. Occupy is different than any other protests this country has seen up to this point. The structure (camping out, consensus, prolonged occupation), its lack of stated goal, the rapid and widespread attraction (there were Occupy camps all over the world), and the sheer number of people 
it claimed to represent (the 99\%), make Occupy different from any other movement, protest, or moment.

Occupy Portland did not change any government policies or persuade corporations to be more humanitarian, but it did change the lives of its participants. Each person I interviewed said that being involved in Occupy has had an effect on them and that they have changed their, behavior, thinking, or involvement as a result. Therefore, it seems, Occupy was more about the actual protest itself than about achieving any sort of goal, more about the means than the ends.

Occupy and Community. What seems to be a consistent in the findings is that people are in search of community. Whether people came to Occupy because they were angry about corporate abuse, as is clear in Chapter 4; or they came because they wanted to be a part of something larger than themselves and they saw Occupy as a place for that (Chapter 5), or they had needs they were trying to meet, as were the findings in Chapter 6; people were searching for community. Participants wanted to feel a since of belonging and were searching for recognition and empowerment, features which people thought they could find at Occupy.

Connected to the search for community there seems to be a feature of Occupy that is unifying, that brought people together. The term solidarity is often used during protests to express the connection protesters share in feeling a common grievance, and Occupy is no exception. Here the group that Occupy represents is referred to as "the 99\%." Many people, including the participants in this study, were drawn to Occupy 
because they felt disenfranchised. There is a feature of Occupy that united people through the shared disenfranchisement.

Therefore, if any theory can be gleaned from this research and applied to future movements or protest activities it is that providing protesters with a sense of community will attract others and likely lead to the sustainability of the protest itself. The issue remains, however, of how organizers can foster this feeling of shared community and execute the activities necessary for a successful campaign. If energy is being put into building community where is the energy for building the campaign supposed to come from? How can organizers both foster community and focus on the purpose of the protest itself? These are questions for further inquiry and research, or perhaps just a look at how movements were able to achieve this balance in the past.

Occupy was successful in building community during the encampments, but increasingly those who were not contributing to the camps or attending the protests were staying in the camps and using up resources. Therefore, the sustainability of this kind of community is called into question. Occupy lasted as long as it did because of the effort and coordination of many, but what the fate of the encampment would have been, had it been allowed to persist, is unclear.

Occupy and Emotion. A salient and consistent theme among all of the participants was that people felt deeply emotional about the issues that brought them to Occupy, whether they are corporations, student loans, or American corporate abuse abroad. In exploring the reasons why people participate, it is clear that emotions played a significant role in bringing people to protests and in maintaining the momentum of 
Occupy. There was a deep anger behind those that came to Occupy because of corporate abuse. Additionally, people came to participate in Occupy because they were looking to be empowered and looking to connect emotionally with those that felt similarly. Some participants became involved once they saw that Occupy resonated with many people, when they saw others participating they felt safe to do so as well. I believe that the study of emotions in social movements and protest has a lot of possibility for scholarship. (See Benski and Langman, 2013)

In thinking about Occupy as a moment and keeping my personal experience, and drives for attending, at the forefront of my mind, I cannot help but think: what sort of moment was Occupy? For some, it was a moment of rage, of protest, of screaming and yelling- a moment of release. For other participants, it was a moment of reflection, of community, solidarity, and cohesion. Still some came because of the immense hope they felt, from being part of something bigger than them, there was hope that ideas such as fairness, equality, and social justice may inspire people enough to demand change. They had hope that their economic situation, or the economic situation of others who are suffering, may soon turn around. For me, and those who participated in this study, it was a combination of more than just one of the above features, but a moment that encapsulated all of them.

The talks that I had with participants conveyed deep emotion and feeling, and people spoke of their strong beliefs, that brought them to become involved in Occupy. For them, and for me, it was a moment of transition after which we will not be the same. Each person mentioned that they are different because of Occupy or are pursuing 
something they are interested in because of the excitement Occupy sparked in them. Bobby is more conscious of the products she uses and where she puts her money. Tiffany, Felix, and Roxy are continuing on with projects that were conceived of during Occupy. Sarah and Brian are both actively advocating for causes they feel strongly about and say they would not be doing so if not for their participation in Occupy Portland. Tedd is dedicating significant time and effort into completing a study about Occupy. As for me, since the day I first heard about Occupy I ceased feeling shame and loneliness about what happened to my family. I hope to continue scholarship on this topic and feel truly hopeful about the power of community. My mother and younger brothers have a roof over their head, and just last week my mother drove home a car of her own for the first time since we lost everything.

\section{Implications and Recommendations}

I embarked on this study to find the principal reasons why people participated in actions associated with Occupy Portland. I sought an answer to this question in order to advise protest organizers and social movement coordinators on how to appeal to those who may be inclined to participate. Additionally, I chose to write about Occupy, because I wanted to bring the conversation that this moment started into academic dialogue, lending it legitimacy and pushing the inquiry further.

Conflict resolution scholars and practitioners can better understand protest participants by looking at the underlying needs surrounding protest activity. This study indicated that participants took part in Occupy activities because they were trying to meet needs, and felt that Occupy Portland was an opportunity for that to occur. According to 
needs based theory, a prevailing theory in conflict resolution, conflicts arise where a party perceives that their needs are not being met or fear that there will be a time when they will not be met. This information gives CR practitioners a new lens through which to identify possible sources of contention or incidents of protest. This recognition gives practitioners an opportunity to intervene encouraging dialogue and promoting the conflict resolution principles of nonviolence and dialogue.

Here also there is room for further research. It may prove useful, to be able to determine why participants felt that these needs would be met by participating in Occupy. Additionally, an inquiry into what mechanisms, or instruments of traditional means of civic engagement, such as voting or participating in community gatherings, failed to meet the needs of participants to such a degree that they felt participation in Occupy was the only way to get these needs met.

Additionally, when thinking about needs, researchers may do well to consider that empathy played a significant role in the participation of participants. Many of the people I interviewed felt that they were not personally affected by the economic crisis, but participated in Occupy because of the harm the crisis caused others. This can be seen in the services such as food and shelter that the camp provided for those that are homeless or mentally ill, along with everybody else at the Occupy camp. The question of whether humans have a need for empathy or whether empathy creates a new set of needs is also ripe for further exploration.

Another very notable and glaring theme that appeared in many of the interviews is that participants seemed to refer to government and corporations interchangeably. There 
was mention of the relationship between corporate malfeasance and its implications for American democracy. However, the use of the term "system" by many participants seemed to refer to both corporate/economic features as well as political or democratic elements. Further questioning and research into the roots of this intermingling may provide insight into participant's view of the economy and government.

Another feature that I noticed from the interviews is what was not mentioned as reasons for participating. A very noticeable feature of OPDX, and many Occupy encampments around the country is their self sustainability and environmental awareness, however environmental activism or protecting the environment was not cited as a reason for participation. This could be one of those topics that are an implied aspect of corporate reform or a restructuring of our economic and political system, or perhaps it is something that is not at the forefront of people's minds when thinking about economic reform. Additionally, there is the possibility that the culture in Portland implies environmental awareness and sensitivity. Whatever the reason may be, this can prove to be a useful area of inquiry for future research.

Finally, the feature that came up most frequently and that is most ripe for further scholarship is the relationship between emotions and motivation to protest. Participants' emotional reactions and emotional states are what brought them to the actions. Whether they were looking for others to share these deep emotions with or were themselves so moved by emotions that they were compelled to participate, it is clear that emotions played a significant role in participation. There is space for scholars to expand on this topic, and perhaps seek out participants who were motivated by other factors outside of 
emotion, or to further enhance a theory based on emotions as a principle motivation for participation. 


\section{References}

Ahern, K. J. (1999). Ten tips for reflexive bracketing. Qualitative Health Research, 9(3), 407-411.

American Student Assistance Program. (2012). Student loan debt statistics. Available from: http://www.asa.org/policy/resources/stats/

Baker, A., Moynihan, C., Nir, S.M. (2011). Police arrest more than 700 protesters on Brooklyn bridge. New York Times. Retrieved from http://cityroom.blogs.nytimes.com/2011/10/01/police-arresting-protesters-onbrooklyn-bridge/

Batchelor, L. (2011, October 6). Occupy wall street lands on private property. CNN. Retrieved from http://money.cnn.com/2011/10/06/news/companies/occupy_wall_street_park/inde $\underline{\text { x.htm }}$

Benski, Tova and Lauren Langman, 2013 The effects of affects: The place of emotions in the mobilizations of 2011, Current Sociology, 61: 525-540 originally published online 17 April 2013.

Bloombergville Now! (2011, June 6). Bloombergville now! sleep out, speak up and fight back against budget cuts! Retrieved from http://bloombergvillenow.org/

Bureau of Labor Statistics, http://data.bls.gov/map/MapToolServlet

Byrne, J., \& Wells, R. (2012). The occupy handbook. New York, NY: Back Bay Books.

Cohen, J.L. (1985) Strategy or Identity: New Theoretical Paradigms and Contemporary Social 
Movements. Social Research, 52(4), 663-715.

Culture Jammers. (2011, July 13). \#Occcupywallstreet: A shift in revolutionary tactics.

[Web log comment]. Retrieved from

http://www.adbusters.org/blogs/adbusters-blog/occupywallstreet.html

Democracy NOW [Video file]. Retrieved from

http://www.democracynow.org/blog/2011/6/24/welcome_to_bloombergville_new _york_activists_fight budget_cuts_by_camping_in_front_of_city_hall

Eyerman, R., \& Jamison, A. (1991). Social movements: A cognitive approach. University Park, Pa: Pennsylvania State University Press.

Freeman, J., \& Johnson, V. L. (1999). Waves of protest: Social movements since the sixties. Lanham, MD: Rowman \& Littlefield Publishers.

Johnston, K. (2011). Public Space and Protest: An Ethnographic Analysis of Alpha and Beta Camps at Occupy Portland.

Klein, N. (2008). The shock doctrine: The rise of disaster capitalism. New York, NY: Picador.

Kriesberg, L. (2012) Constructive conflicts: From escalation to resolution. Lanham, MD: Rowman \& Littlefield.

Krugman, P. \& Wells, R. (2012). The widening gyre: Inequality, polarization and the crisis. In J. Byrne (Ed), The Occupy handbook (pp. 7-17). New York, NY: Back Bay Books. 
Leberstein, S. \& Christman, A. (2012). Occupy our occupations: Why "we are the 99\%" resonates with working people and what we can so to fix the American workplace. Fordham Urban Law Journal, 39(4): 1073-1105.

McAdam, D., Snow, D. A., \& McAdam, D. (2010). Readings on social movements: Origins, dynamics and outcomes. New York, NY: Oxford University Press.

McAdam, D., Tarrow, S., \& Tilly, C. (2001). Dynamics of contention. Cambridge, England: Cambridge University Press.

McCarthy, J. D., \& Zald, M. N. (1977). Resource Mobilization and Social Movements: A Partial Theory. American Journal of Sociology, 82(6), 1212-1241.

Meyer, D. S. (2007). The politics of protest: Social movements in America. New York, NY: Oxford University Press.

Morris, A. D., \& Mueller, C. M. C. (1992). Frontiers in social movement theory. New Haven, CT: Yale University Press.

Polletta, F., \& Jasper, J. M. (2001). Collective identity and social movements. Annual Review of Sociology, 27, 283-305.

Roy, B., Burdick. J., \& Kriesberg L. (2010). A conversation between conflict resolution and social movement scholars. Conflict Resolution Quarterly, 27(4), 347-368.

Saker, A. (2011). Occupy Portland: Portland State students, faculty open their front with rally, march, a burning sheepskin. Retrieved from: http://www.oregonlive.com/portland/index.ssf/2011/11/occupy_portland_portland state_1.html

Sharp, G. (1980) Social power and political freedom. Boston, MA: Extending Horizons. 
Starks, H. and Trinidad, S. B. (2007) 'Choose Your Method: A Comparison of Phenomenology, Discourse Analysis, and Grounded Theory', Qualitative Health Research 17(10): 1372-80.

Tarrow, S. (1998) Power in Movements: Social movements and contentious politics. Cambridge: Cambridge University Press.

Taylor, A., \& Gessen, K. (Eds.). (2011). Occupy! scenes from occupied America. London, England: Verso.

Tufford, L., \& Newman, P. (2012). Bracketing in Qualitative Research. Qualitative Social Work, 11(1), 80-96. 


\section{APPENDIX A \\ $\underline{\text { Human Subjects Research Proposal }}$}

II. Project Title \& Prospectus

\section{Why Occupy?: Factors that Contribute to Participation in the Occupy Portland}

\section{Movement}

I seek to answer the question: why did people participate in Occupy Portland (OPDX)? I will interview ten people who participated in the original march and rally on October $6^{\text {th }} 2011$ and at least two Occupy related events thereafter. Following the interviews I will transcribe what the participants have told me and code what I find, identifying common themes among the interviews. These themes will inform my analysis from which I will draw my conclusions. The goal of this project is to determine the political, social, and/or economic environment that precipitates social movements. The purpose of such research is to aid those who participate in social movements to appeal to others who would benefit from the change the movement seeks to achieve.

III. Type of Review

Full committee review.

IV. Subject Recruitment

The informants will include people who have participated or continue to participate in the OPDX movement. I will conduct the interviews in person; therefore it will include people who are located in the Portland vicinity at the time of the interview. I will do ten interviews and will recruit the participants through connections I have 
garnered by my own involvement in the OPDX movement. My criteria for selection will be determined by the demographic parameters discussed above. I also intend to have a minimum level of participation in the movement as criteria for inclusion. Each participant will have attended the first march and rally, which took place on the first day of Occupy Portland- October $6^{\text {th }}$ 2011, and at least two subsequent events. No formal documentation of attendees at these actions exists, therefore my criteria and verification for participation will be based on the self report of my informants. I will trust that they were present at the actions and events at which they claim to have been present. If I find that people are unable to participate in my study or that the connections I have are insufficient or do not meet my criteria, I will ask the people I am acquainted with for recommendations of others within the movement. I am confident that this networking will be sufficient for me to recruit enough participants.

\section{Informed Consent}

I will obtain consent for the interview first informally by initially contacting the participants and asking them if they will participate in my study. If they agree I will have a written consent form (see appendix), which I will ask them to sign and date at the time of the interview. I intend to have all participants be over the age of 18 and mentally competent.

\section{First-Person Scenario}


Danielle and I have been friends for a little while, seeing each other at OPDX events and having friendly conversation and connections over our shared passions. Therefore, when she called and asked me if I would be interested in participating in her study about Occupy Portland I was happy to say yes. She asked me what type of environment I would feel most comfortable doing the interview- offering suggestions such as coffee shops, the Portland State Library, or one of our apartments. I told her that a coffee shop was fine with me, so we agreed to meet at Red and Black Cafe across from the Occupy Portland office.

We met on Thursday afternoon and sat at a small table over to the side. Danielle took out a piece of paper, titled "informed consent" and asked me to read over it very carefully and sign and date at the bottom, then she provided me with my own copy of this document. Once I did that she told me that my anonymity would be protected and my identity kept secret during all points of the study and asked what pseudonym I would like her to use to refer to me in her research. Next, Danielle asked if she could record the conversation and take some notes as I was talking. I felt fine with that request, since I knew she needed to do this in order to properly complete her research.

The first question she asked me is why I became involved in the Occupy movement in the first place. As I told her my story she asked follow up questions, mostly pertaining to why I became involved in Occupy. I found the interview interesting; it gave me a chance to reflect on why this movement is so important to me and provided a space for me to talk about some of the very personal reasons why I was drawn to Occupy in particular. The whole interview took about an hour, and when we were done Danielle 
asked me if I wanted to say anything else about Occupy before she turned off the recorder, I told her I did not. She turned off the recorder and reminded me again about the safety of my identity. She then thanked me for participating and I gave her my email address to send me a final copy of her thesis and information about when she will be defending. Danielle left the coffee shop and I stayed to get some homework done while I was there, all in all it was a good experience and I am glad to have an opportunity to be involved.

VII. Potential Risks and Safeguards

At this point it would seem that involvement in the interview will not put subjects at any more risk than involvement in the Occupy movement in general. Government officials have raided the private homes of those who have participated in the Occupy movement, using flash grenades and violent tactics. However, any justification for raids or other sort of intervention on the part of law enforcement agents will not be fueled by this interview.

Because of the nature of the Occupy movement and the reasons that people get involved there is concern about discussing uncomfortable life events. There are people who have lost their homes and have suffered substantially from the downward spiral of the world economy, the Occupy movement is based on the premise that corporate greed and corruption has contributed to this loss. Therefore, inquiring about my subject's involvement and attraction to the movement may necessitate that they recount difficult 
events such as losing a house, being unable to pay for healthcare for a loved one, relationship turmoil related to money, job loss, being houseless, inability to provide for their family, or frustration and despair. This may cause subjects to experience discomfort and agitation, perhaps even anger in some cases. If I notice that their reactions to my questions or our conversations become overwhelming I will stop the interview. If I notice a slighter form of sadness I can redirect the conversations to what the subject hopes the movement will provide. Overall I do not believe that the discomfort experienced by subjects during the interview will cause enough harm to warrant significant intervention or justify the denial of this application.

\section{Potential Benefits}

The benefits of participation in the study are both direct and indirect. The subjects of this study will be provided with an opportunity to tell their story and have that contribute to a tangible study that they can read and have the satisfaction of knowing they participated. I feel that by including participant's stories as part of an academic study, it helps to legitimize their experience. It allows people to transform anger and frustration into something positive and helpful. More indirectly, the results of this study will tell us what draws people to social movements, which can be useful in framing and outreach. Often social movements take fail to show immediate results and gather momentum early, it may be easier to attract participants if leaders know how to appeal to those who find that the movement serves their needs. The goal of this study is to reveal why people are 
attracted to Occupy Portland and I believe that the trends and patterns that are uncovered by my research will provide some insight into the motivations of those who become involved and useful members of social movements.

IX. Confidentiality, Records \& Distribution

In order to maintain confidentiality each participant will choose their own pseudonym for reference in my research. Any reference to the individual in my notes or research will use the pseudonym. I will store the data collected from participants on a hard drive at Portland State University. I plan to audio record the interviews and transcribe the audio version, which I will later code and try to find themes and commonalities among the answers, these themes will comprise the data for my thesis. The whole process can be done with minimal reference to individual subjects. I will digitally record the interview and keep the audio recordings on the PSU server for a time period of three years, after which I will permanently delete the files. All interviews, data, and files will be password protected at all times. Even the thesis itself is going to be written on a password protected computer that is consistently in my possession and limited to my personal access.

X. Training and Experience 
I have completed all coursework required for a master's degree in the Conflict Resolution Department. Such coursework includes a graduate level research methodology class, which has familiarized me with research processes, ethics, and methodology. Additionally, in completing my coursework, I have read a number of studies and have consequently become familiar with research processes and requirements.

XI. Appendices

[Informed Consent]

\section{Why Occupy?: Factors that Contribute to Participation in the Occupy Portland Movement}

You are invited to participate in a research study conducted by Danielle Filecia from Portland State University, Department of Conflict Resolution. The researcher hopes to learn, specifically why residents of Portland were motivated to participate in the Occupy Portland movement and more generally what draws people to social movements. I am conducting this study in partial fulfillment of the requirements for my master's degree. This study is being done under the supervision of Robert Gould PhD (503-725-3502, Neuberger Hall 239, 724 SW Harrison, Portland, OR 97201) at Portland State. You were selected as a possible participant in this study because of your participation in Occupy Portland. 
If you decide to participate, you will be asked to talk about the reasons you participated in these events and the factors that influenced your continued involvement. The interview will last no longer than one hour and will take place at a location that is agreeable and comfortable for you. I will be audio recording our interview in order to capture all that we discuss today and the audio recording will be kept confidential and used only for the purposes of this research project. While participating in this study, it is possible that you may be discussing feelings and motivations that are personal, which runs the risk of causing you discomfort. If the discomfort that you feel in discussing these topics becomes overwhelming or intolerable please notify me immediately and we can pause the interview or end it altogether. This research involves a small number of subjects in a small setting about a specific event(s). Although I will take measures to protect your confidentiality, it is possible that unique stories or unique demographic information could lead to someone identifying you. You may not receive any direct benefit from taking part in this study, but the study may help to increase knowledge which may help others in the future.

Any information that is obtained in connection with this study and that can be linked to you or identify you will be kept confidential. This information will be kept confidential by using a pseudonym to you, which you can choose if you would like. After I have completed all of the voice recorded interviews I will transcribe them into written form and will go through each interview and code them looking for common themes and topics. These themes and topics will be used as for my thesis, and any reference to you 
personally will not be included. I will store the data on a private password protected server at PSU. I will be using the data in my thesis, which I will complete using my laptop computer, which is itself password protected. I will keep a digital record of our interview on a password protected Portland State server for three years, as mandate by federal law. After the three years is up I will delete these recordings permanently.

Your participation is voluntary. You do not have to take part in this study, and it will not affect your relationship with Portland State University, Occupy Portland, or me. You may also withdraw from this study at any time without affecting your relationship with Portland State University, Occupy Portland, or me.

If you have questions or concerns about your participation in this study, contact Danielle Filecia at (323) 806-2463 or fileciad@pdx.edu. If you have concerns about your rights as a research subject, please contact Research and Strategic Partnerships, Market Center Building $6^{\text {th }}$ floor, Portland State University, (503) 725-4288.

Your signature indicates that you have read and understand the above information and agree to take part in this study. The researcher should provide you with a copy of this form for your own records.

Signature

Date

Print name 


\section{APPENDIX B}

Interview Questions

Have you been to a protest before Occupy Portland?

What is/was your involvement with Occupy Portland? What events/actions did you attend?

Why did you decide to participate in Occupy Portland?

Are you still involved with Occupy Portland or any affinity groups that were started from the initial Occupation?

At the time of your involvement what did you think the values and principles represented by Occupy Portland were? What do you think they are now?

Do you have any personal connection to the values or principles represented by Occupy Portland? Would you feel comfortable talking about these?

Have any of the circumstances in your own life led you to participate in Occupy Portland?

Did you know anyone already involved when you first participated? If not how did you first hear about it?

Do you think others have participated in Occupy Portland for the similar reasons? Will you participate in another protest or social movement campaign? Why or why not? 


\section{Appendix C: Participant Demographic Information}

\begin{tabular}{|l|l|l|l|l|l|}
\hline $\begin{array}{l}\text { Name } \\
\text { (Pseudonym) }\end{array}$ & Gender & Age & $\begin{array}{l}\text { College } \\
\text { Attendance }\end{array}$ & $\begin{array}{l}\text { Was OPDX } \\
\text { your first } \\
\text { protest? }\end{array}$ & $\begin{array}{l}\text { Will you } \\
\text { attend } \\
\text { Protest } \\
\text { again }\end{array}$ \\
\hline Brian & Male & 20 's & Yes & Yes & Yes \\
\hline Sarah & Female & Early 20's & Currently & No & Yes \\
\hline Bobby & Female & Mid 20's & Yes & No & Yes \\
\hline Tedd & Male & Early 30's & Yes & No & Yes \\
\hline Roxy & Female & Mid 20's & Yes & No & Maybe \\
\hline Tiffany & Female & 20 's & Currently & No & Yes \\
\hline Felix & Male & 30 's & No & No & Yes \\
\hline
\end{tabular}

